\title{
微粉炭燃佬におけるサーマル NO $x$ の生成機㮆に関する基礎的研究*
}

\author{
岡崎 健*1, 杉山一夫*2, 百 合 功*2 \\ Study on the Formation Mechanism of Thermal NO
in Pulverized Coal Combustion
}

\author{
Ken OKAZAKI, Kazuo SUGIYAMA and Isao YURI
}

\begin{abstract}
Effects of various basic factors of combustion conditions and coal properties on thermal $\mathrm{NO}_{x}$ formation behaviors in pulverized coal combustion have been experimentally clarified, and a theoretical analysis for the flame structural change around a coal particle has been performed including full chemical kinetics of prompt $\mathrm{NO}_{x}$ formation. Thermal $\mathrm{NO}_{x}$ concentrations much higher than that predicted by the extended Zeldovich mechanism have been experimentally observed even in the usual pulverized coal combustion conditions. The contribution of thermal $\mathrm{NO}_{x}$ to the total $\mathrm{NO}_{x}$ rapidly increases with the increases of flame temperature and oxygen-fuel stoichiometric ratio especially for high volatile coals. Both the large amount of thermal $\mathrm{NO}_{x}$ formation and effects of various factors on it have been well explained by considering the prompt $\mathrm{NO}_{x}$ formation in the flame zone around each particle through $\mathrm{HCN}$ and $\mathrm{NH}$ formed by the reactions between $\mathrm{N}_{2}$ in air and hydrocarbons in the evoluted volatile matter.
\end{abstract}

Key Words: Combustion Products, Chemical Reaction, Pulverized Coal Combustion, NO $x$ Formation. Thermal NO$x$, Furnace, Solid Fuel.

\section{1. 䋖}

微粉炭燃焼において生成される環境污染物質の中で も，特に $\mathrm{NO}_{x}$ (窒素酸化物)の生成挙動は複雑で，その 生成漊度は，炭種性状はもちろん燃焼炉内での燃焼条 件，特に微粉炭と空気の混合過程に起因する局所条件 の影翼を強く受ける ${ }^{(1)(2)}$ 。このことが，多段燃焼や低 $\mathrm{NO}_{x}$ バーナによる適切な燃焼制御を行うことにより， 炉内での $\mathrm{NO}_{x}$ 生成を大幅に抑制することを可能とし ている。一般に石炭中には $1 \%$ 程度の窒素分（N 分） が含まれており、これがすべて $\mathrm{NO}_{x} に$ 転化したとす ると約 $2000 \mathrm{ppm} に も$ 達するにもかかわらず，最近の 高度な低 $\mathrm{NO}_{x}$ 燃焼技術の進步により，炉出口での $\mathrm{NO}_{x}$ 濃度を排煙脱硝なしでも $150 \mathrm{ppm}$ 程度にまで低隇て



従来，微粉炭燃焼において生成される $\mathrm{NO}_{x}$ の大部 分は，原炭中の $\mathrm{N}$ 分に起因するフュエル $\mathrm{NO}_{x}$ である と考えられており ${ }^{(1)(4)}$ ，低 $\mathrm{NO}_{x}$ 燃焼技術の開発 ${ }^{(3)}$ も。 このフュエル $\mathrm{NO}_{x}$ の生成抑制に重点が置かれていた。 また, $\mathrm{NO}_{x}$ の生成挙動やその抑制法に関する基整研究

*原稿受付 平成元年: 111327 日

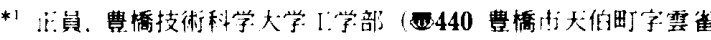
分 $1-1$ )

*2 豊橋技街科学大学大学院
$も^{(5) \sim(10)}$, 全 $\mathrm{NO}_{x}$ の生成挙動をフュエル NO のとみなして検討したものがほとんどであった。しか しながら，上記のように全 $\mathrm{NO}_{x}$ 生成量が極度に低隇 されてくると、これまであまり重要視されていなかっ た，空気中の $\mathrm{N}_{2}$ を起源とするサーマル $\mathrm{NO}_{x}$ の寄与が 無視できなくなってきた。したがって，さらなる極低 $\mathrm{NO}_{x}$ 燃焼技術の開発を進めるうえでの基本的な指針 を得るためには、フュエル $\mathrm{NO}_{x}$ とサーマル $\mathrm{NO}_{x}$ を分 離したうえで,サーマル $\mathrm{NO}_{x}$ の生成挙動に及ほす 種々の主要因子の影響を明らかにしておくことが必要 である.これまでに, Pershing らによりサーマル NO $x$ の分離測定が行われた例(4) はあるが，サーマル $\mathrm{NO}_{x}$ そ のものの生成挙動と、これに及ほす諸因子の影響につ いて詳細に検討された例はない。

本研究は，炉内に混合過程がなく諸因子の純粋な影 響を抽出するのに適した，層流一次元の最も単純な燃 焼場 ${ }^{(9)}$ を用いて，微粉炭燃焼におけるフュエル NOx サーマルNOx 実験的に分離し，それぞれの生成挙 動に及ぼす燃焼条件や炭種性状などの諸因子の影響を 系統的に明らかにするとともに，粒子まわりの火炎帯 での反応動力学に関する理論解析と合せて，それらの 要因について検討を行ったものである。その結果，サ ーマル $\mathrm{NO}_{x}$ の生成量は、燃焼条件によっては拡大 
Zeldovich 機構により予測される值よりもはるかに大 きく，これが，粒子まわりの火炎帯で生成されるプロ ンプト $\mathrm{NO}_{x} に$ 起因していることが明らかにされた。 な お,プロンプト $\mathrm{NO}_{x}$ はもともと，炭化水素の然料過漕 予混合火炎帯で急速に生成されることからその名があ る(11)が，微粉炭粒子から揮発分として気中に放出され た炭化水素と空気中の $\mathrm{N}_{2}$ との反応によって生成され る $\mathrm{HCN}, \mathrm{NH}_{i}$ を経由する $\mathrm{NO}_{x}$ を，慣例にならってプ ロンプト $\mathrm{NO}_{x}$ と称することにする.

\section{2. 实伢装置および实験方法}

実験装置は図 1 に示すとおりであり，内径 $8 \mathrm{~cm}$, 長 さ $1.5 \mathrm{~m}$ の層流式一次元微粉炭燃焼炉である. 微粉炭 は空気と十分均一に混合された後, 冷却グリッドを通 過して炬内に流入し，下向きに一次元燃焼する．本実 験装置は，前報(9)で用いたものとほほ同様であるがや や小形化され，また，フュエル $\mathrm{NO}_{x}$ とサーマル $\mathrm{NO}_{x}$ を分離するために，新たに, $\mathrm{Ar}$ (アルゴン) 流路と $\mathrm{O}_{2}$ (酸素) 流路が設けられている。ささらに, 火炎温度が任 意に設定できるように,シリコニット発熱体による空 気予熱器が設置されている。これらにより，酸素過剩 率 $\lambda$, 最高火炎温度 $T_{\max }$, 初期酸素モ儿浱度 $R_{\mathrm{O}_{2}}$ を独 立に変化させることができる， $\lambda$ は， $R_{0_{2}}=21 \%$ 空気 の場合は，いわゆる空気比に対応する。

フュエル $\mathrm{NO}_{x}$ とサーマル $\mathrm{NO}_{x}$ の分離は, 通常の空 気 $\left(\mathrm{N}_{2}+\mathrm{O}_{2}\right)$ による燃焼実験と, 空気中の $\mathrm{N}_{2}$ を $\mathrm{Ar} に$ 置き換えた燃焼実験の両者の比較により行った。すな わち，空気による燃焼実験で得られる全 $\mathrm{NO}_{x}$ と, $\mathrm{Ar}$ $+\mathrm{O}_{2}$ による実験で得られるフュエル $\mathrm{NO}_{x}$ との差とし てサーマル NO $x$ を求めた。このようにして得られたサ 一マル NOxは, 空気による燃焼時に生成しているサ

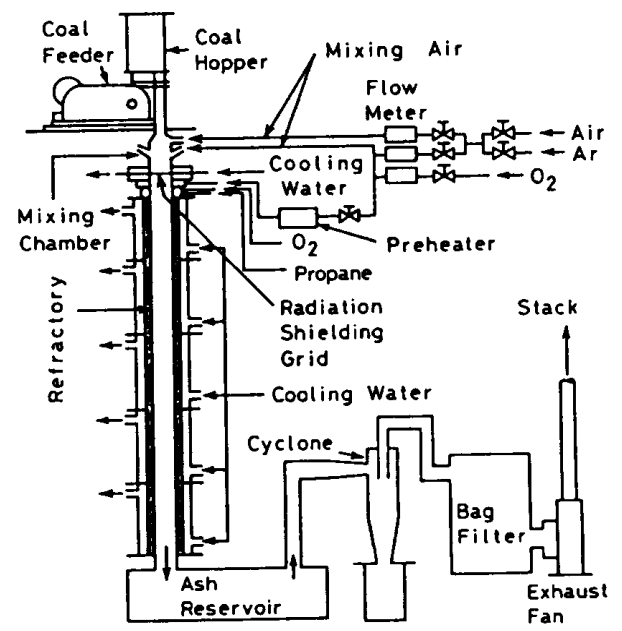

図 1 一次元微粉炭然焼実験炉
一マル $\mathrm{NO}_{x}$ を正しく与える根拠(1)は必ずしもないが, 本手法により，少なくともサーマル $\mathrm{NO}_{x}$ がどのくら い生成されるかの下限は示すことができるものと考え られる。 なお， $\mathrm{NO}_{x}$ の測定には，化学発光式 $\mathrm{NO}_{x}$ 分析 計を用いた。

実験に使用した 3 炭種の工業分析值および元素分析 值を表 1 に示す．揮発分含有率 $V M$ はほほ等しく $\mathrm{N}$ 分含有率 $N$ が大きく異なる $\mathrm{A}$ 炭と $\mathrm{B}$ 炭, $N$ はほほ等 しくVM が大きく異なる $\mathrm{B}$ 炭と $\mathrm{C}$ 炭を供試炭として 採用することにより, 炭種の数は少ないが, 原炭性状 の影響の抽出が可能となる，微粉炭の粒径分布につい ては, いずれの炭種についても 200 メッシュ通過約 85 \%程度である。また，実験条件は， $T_{\max }=1000 \sim 1600$ ${ }^{\circ} \mathrm{C}, \quad \lambda=0.8 \sim 1.4, \quad R_{\mathrm{O}_{2}}=21 \sim 27 \mathrm{~mol} \%$ である.

燃焼条件 $\left(\lambda, R_{\mathrm{O}_{2}}, T_{\max }\right)$ p原炭性状 $(V M, N)$ が大き く異なる条件下での $\mathrm{NO}_{x}$ の生成特性を珫一的に正し く評価するために，実験結果の整理においては， $\mathrm{NO}_{x}$ 濃度そのものではなく，与えられた燃焼条件における 原炭中 $\mathrm{N}$ 分の $100 \%$ 転換 $\mathrm{NO}_{x}$ 湌度に対する $\mathrm{NO}_{x}$ 濃 度を $C R$ 值と定義し，これに及ほすす諸因子の影響を検 討した.フュエル $\mathrm{NO}_{x}$, サーマル $\mathrm{NO}_{x}$, 全 $\mathrm{NO}_{x}$ に対 する $C R$ 值を，それぞれ $C R_{f}, C R_{\mathrm{th}}, C R_{t}$ とする。 こ のうち $C R_{f}$ は, 原炭中 $\mathrm{N}$ 分からフュエル $\mathrm{NO}_{x}$ への変 換率に対応する。ただし，原炭中 $\mathrm{N}$ 分含有率の異なる 場合のサーマル $\mathrm{NO}_{x}$ の比較の場合には， $\lambda=1.0, \quad R_{\mathrm{O}_{2}}$ $=21 \%$ に基準換算したサーマル $\mathrm{NO}_{x}$ 檂度を用いた。火 炎温度の測定には保護管付きの R 形熱電対を用い，ふ く射補正は行っていない。なお, サクション温度計に よる検討の結果, 真の火炎温度は, 熱電対指示温度よ り約 $120^{\circ} \mathrm{C}$ 程度高いことを確認している。

\section{3. 実験結果およひ考察}

炉内中心軸上での火炎温度，および $\mathrm{NO}_{x} の C R$ 值 の分布の代表例を，B炭， $\lambda=1.2 ， R_{0_{2}}=27 \%$ の場合 について図 2 に示す. $\mathrm{N}_{2}+\mathrm{O}_{2}$ による燃焼実験で得ら れた全 $\mathrm{NO}_{x}$ も， $\mathrm{Ar}+\mathrm{O}_{2}$ による燃焼実験で得られたフ エエル $\mathrm{NO}_{x}$ も，最高火炎温度付近に最大值を持ち，そ の後徐々に減少するがほほ一定値を保ちつつ炉出口に 至っている。燃料過濃すなわち $\lambda<1$ の場合には, 後流

表 1 実験に用いた石炭の性状

\begin{tabular}{|c|c|c|c|c|c|c|c|}
\hline Coal & $\begin{array}{c}\text { Proximate } \\
\text { VM }\end{array}$ & $\begin{array}{c}\text { Analys } \\
\text { FC }\end{array}$ & $\begin{array}{c}8(1, d r y) \\
\text { Ash }\end{array}$ & $\begin{array}{c}\text { Uit) } \\
\text { c }\end{array}$ & $\begin{array}{c}\text { nate A } \\
\text { H }\end{array}$ & $\begin{array}{c}\text { Analysi } \\
0\end{array}$ & $\underset{\mathrm{N}(\mathrm{d}, \mathrm{dry})}{ }$ \\
\hline $\boldsymbol{A}$ & 44.4 & 39.8 & 15.8 & 65.4 & 5.47 & 12.5 & 0.79 \\
\hline B & 40.8 & 49.2 & 10.0 & 71.4 & 5.3 & 10.9 & 1.50 \\
\hline c & 26.1 & 58.7 & 15.2 & 70.5 & 3.64 & 8.3 & 1.64 \\
\hline
\end{tabular}


での $\mathrm{NO}_{x}$ 湍度の低下がやや大きくなるが，以後の実 験結果の整理では，すべて炬出口における $\mathrm{NO}_{x}$ 湍度 を用いることにする．また，図 2 からわかるとおり， $\mathrm{Ar}$ のほうが $\mathrm{N}_{2}$ よりかなり比熱が小さいため, $\mathrm{Ar}$ $+\mathrm{O}_{2}$ による燃焼の場合のほうが火炎温度が高くなっ ている. したがって, 図 2 の炉出口での全 $\mathrm{NO}_{x}$ とフュ エル $\mathrm{NO}_{x}$ との差をそのままサーマル $\mathrm{NO}_{x}$ とみなすこ とはできず，ある等しい最高火炎温度条件に対するサ ーマルNOxを抽出するためには，以下のような整理 が必要となる。

3.1 最高火资温度の影害 炉出口における $\mathrm{NO}_{x}$ とフェエル $\mathrm{NO}_{x}$ の $C R$ 值に及ほす $T_{\max }$ の影管を図 3，4 に示す。この両者の差が，その $T_{\text {max }}$ に対するサ 一マル $\mathrm{NO}_{x}$ に相当する. 図 3 は, $\mathrm{A}$ 炭において $\lambda$ を変 化させた場合の結果, 図 4 は, $\lambda=1.2$ で炭種を変化さ せた場合の結果であり,フュエル $\mathrm{NO}_{x}$ とサーマル $\mathrm{NO}_{x}$ が明りょうに分離されている。本実験条件の筙囲では, いずれの場合においても、フュエル $\mathrm{NO}_{x}$ 洤度は $T_{\max }$ にほとんど依存していない，ガスの予混合然焼におい て, $\lambda>1$ ではフュエル $\mathrm{NO}_{x}$ の温度依存性はきわめて 小さいが, $\lambda<1$ の燃料過縟条件下では，温度の低下と ともに $\mathrm{HCN}, \mathrm{NH}_{3}$ 泠度が增加しフュエル $\mathrm{NO}_{x}$ 湍度が

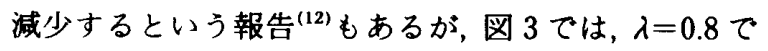
もその影䈍は現れていない。これは，微粉炭燃焼では， 本実験のように予混合然焼をしても，各粒子まわりに ついて見れば拡散燃焼的でもあり，単純にガス然焼に おける結果と比較できないこと，および，チャ一の败 焼速度が遅いため, 原炭中 $\mathrm{N}$ 分が主として気相中に 放出される揮発分燃焼域では，実奻的な $\lambda$ の值が大き くなることによるものと考えられる。

これに対し，サーマル $\mathrm{NO}_{x}$ の生成は, $T_{\max }<1200$ ${ }^{\circ} \mathrm{C}$ ではほとんどないが, $T_{\max }$ の上昇に伴い急激に増

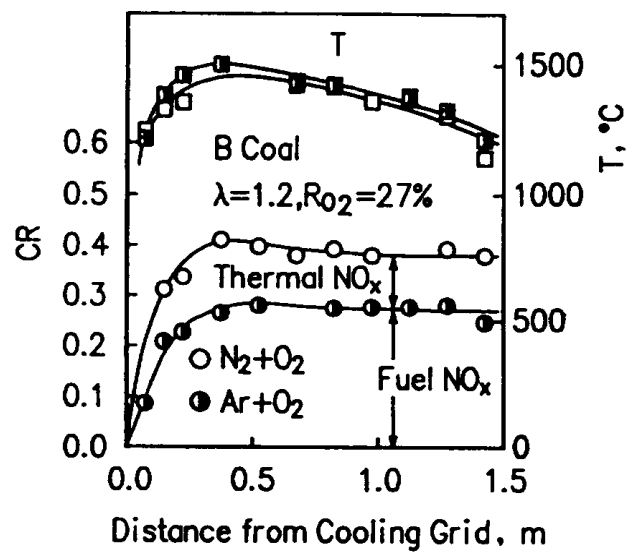

図 2 火炎温度, および, 全 $\mathrm{NO}_{x}$ とフュエル $\mathrm{NO}_{x}$ の 妒中心軸上分布
大する.この傾向は、 $\lambda$ が大きいほど,また, $V M$ が大 きい炭種ほど頼著に現れている。Ａ成の $\lambda=1.2$ の場 合, $T_{\max }$ が $1300^{\circ} \mathrm{C}$ から $1500^{\circ} \mathrm{C}$ に上昇するに従い, サ ーマル $\mathrm{NO}_{x}$ の全 $\mathrm{NO}_{x}$ に対する寄与率は, $11 \%$ \%ら 35 \%にまて增加しており，一般に微粉炭然燒ボイラに対 応する条件下でも，サーマル NOxを軽視することは できないことがわかる。

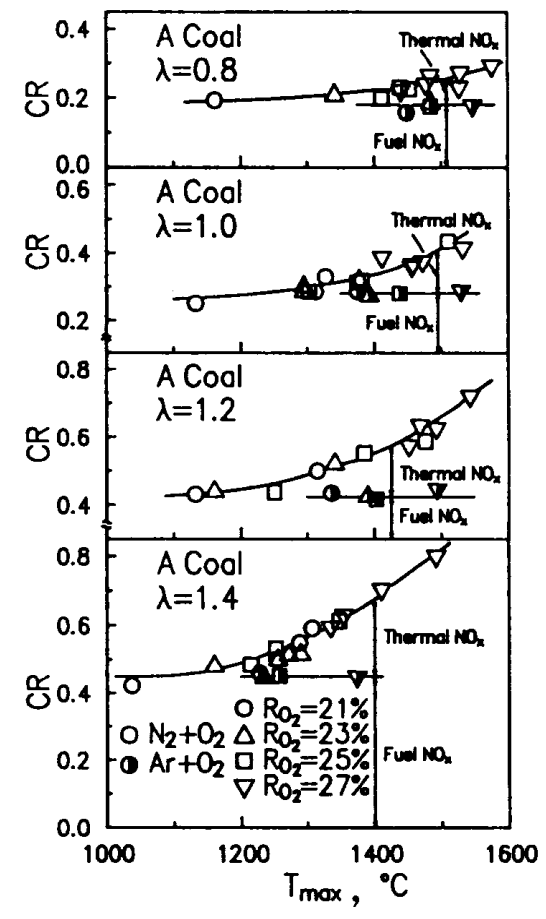

(酸素過剩率に上る差異，A炭の場合)

図 3 NOx生成に及ほす最高火炎温度の影

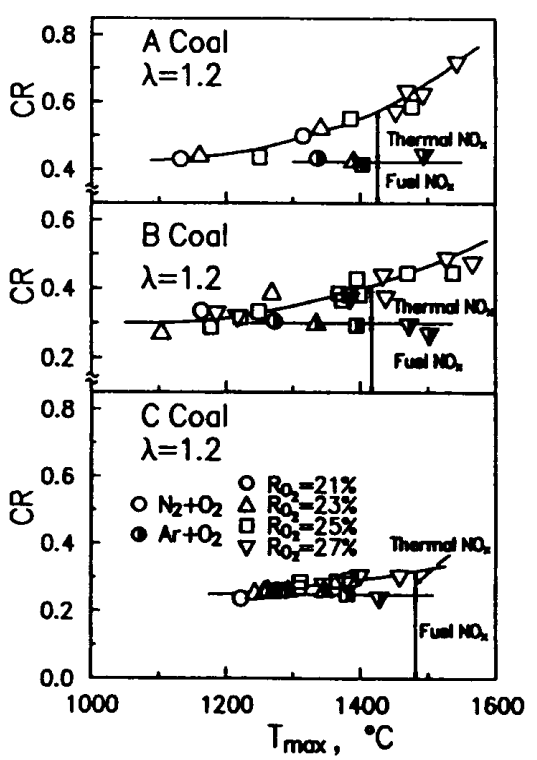

(炭種に上る差異, $\lambda=1.2$ の場合)

図 $4 \mathrm{NO}_{x}$ 生成に及ほす最高火炎温度の影 
$T_{\max }$ の上昇とともにサーマル $\mathrm{NO}_{x}$ が增加すること

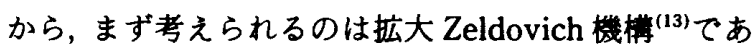
る.これによって生成されるサーマル $\mathrm{NO}_{x}$ をここてて はZ Zeldovich $\mathrm{NO}_{\boldsymbol{x}}$ と称することにする。一般にZeldovich $\mathrm{NO}_{x}$ は火炎帯後流で生成されること，また， 揮発分然焼はきわめて短時間で完了することから，揮 発分燃烧後の $\mathrm{O}_{2}$ 灌度を初期值として, Zeldovich $\mathrm{NO}_{x}$ 浱度の計算を行った，A 炭， $\lambda=1.2$ の場合の結果を温 度 $T$ をパラメータとして図 5 に示す。図 5 中の破線 は，実験に対応する炉内滞留時間を表している。この 結果によると, Zeldovich $\mathrm{NO}_{x}$ 港度は, $T=1800 \mathrm{~K}$ で $1 \mathrm{ppm}, T=2000 \mathrm{~K} て ゙ も 40 \mathrm{ppm}$ 程度であり, 図 6 の $\mathrm{A}$ 炭の場合に示されているサーマル $\mathrm{NO}_{x}$ 濃度より はるかに小さい。この差は, 実際の火炎温度は $T_{\max }$ 上 り約 $120^{\circ} \mathrm{C}$ 程度高いこと，および，揮発分㜣焼時にお ける粒子温度が, 平均火炎温度より数百 ${ }^{\circ} \mathrm{C}$ 程度も高く なり得るこど(14)を考虑しても全く説明できない．

本研究では,この差をある程度説明し得る Zeldovich $\mathrm{NO}_{x}$ 以外のサーマル $\mathrm{NO}_{x}$ 生成機構として, 粒

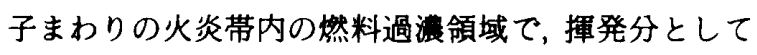
放出された炭化水素と空気中の $\mathrm{N}_{2}$ との反応によって できる $\mathrm{HCN} や \mathrm{NH}_{i}$ を経由するプロンプト $\mathrm{NO}_{x}$ を考 え，4章において詳細な理論的検討を行っている。 そ の結果, 微粉炭燃焼におけるサーマル $\mathrm{NO}_{x}$ のかなり の割合が, プロンプト $\mathrm{NO}_{x}$ に起因していること,ま た，一般には温度依存性が小さいと言われているプロ ンプト $\mathrm{NO}_{x}{ }^{(15)(16)}$ も，温度上昇に伴う粒子まわりの火 炎帯の拡大を介して温度の影響を強く受けることが示 される。

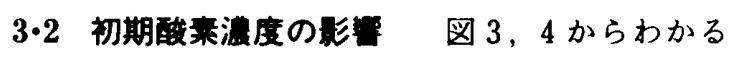
とおり，R $R_{\mathrm{O}_{2}}$ が異なるにもかかわらずフュエル $\mathrm{NO}_{x}$ も サーマル $\mathrm{NO}_{x}$ それぞれ一つの線上に重なっており， これらに及ほす $R_{0_{2}}$ の影整はきわめて小さい. $T_{\max }$ が 等しくても， $R_{0_{2}}$ が大きいほど粒子近傍温度が高くな ク, サーマル $\mathrm{NO}_{x}$ の生成が多くなることが予想され

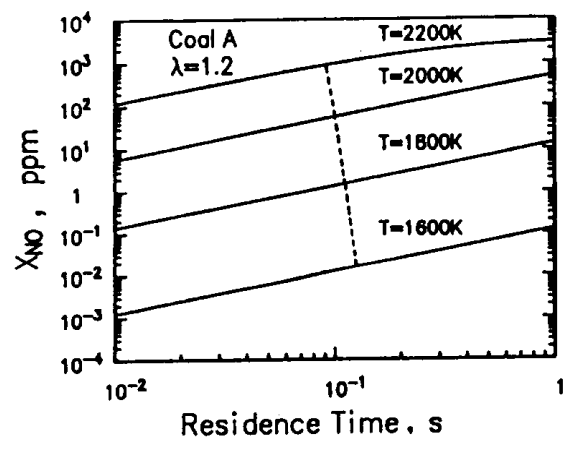

図 5 拡大 Zeldovich 機粸によるサーマル $\mathrm{NO}_{x}$ 生成量
るにもかかわらずこのような結果となるのは， $R_{\mathrm{O}_{2}}$ の 增加により揮発分然焼域での粒子まわりの火炎帯が縮 小し，プロンプト $\mathrm{NO}_{x}$ の生成が抑えられることによ るものと解釈することができる。


た図 3 と同様なデー夕から， $T_{\max }$ を固定したときの, フェエル $\mathrm{NO}_{x}$ とサーマル $\mathrm{NO}_{x}$ に対する入の純粋な影 響を抽出した。その結果を, A,B,C炭について図6に 示す. サーマル NO は $\lambda$ の増加とともに增大し, この 効果は, $T_{\max }, V M$ が大きいほど顕著である. $\lambda$ が大き くなるとサーマル $\mathrm{NO}_{x}$ の生成量が多くなるのは, Zel-

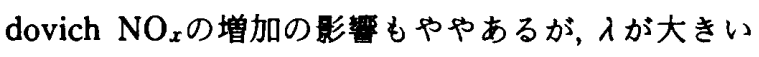
ほど, 揮発分燃焼時に粒子まわりの火炎帯外部に十分 な $\mathrm{O}_{2}$ が存在し, 火炎带内部で生成された $\mathrm{HCN} ゃ$ $\mathrm{NH}_{i}$ の $\mathrm{NO}_{x}$ への変換が容易になるためであると考え られ，炭化水素予混合火炎でのプロンプト $\mathrm{NO}_{x}$ が，主 としてネ<1の然料過湌条件のもとで生成される場 合(15)(17) とは，状況を異にしている。これに対しフュエ ル $\mathrm{NO}_{x}$ の $C R_{f}$ は, $\lambda<1.2 て ゙ は \lambda の$ 增加とともに增大 するが, $\lambda>1.2$ では明らかな館和傾向を示している. この傾向は，炭化水素燃焼の予混合火炎の場合 ${ }^{(18)}$ や, 平均空気比を用いて整理した層流拡散火炎の場合(19) の結果と非常に良く一致している.

図 6 では，基準換算した $\mathrm{NO}_{x}$ 浀度が合せて示され



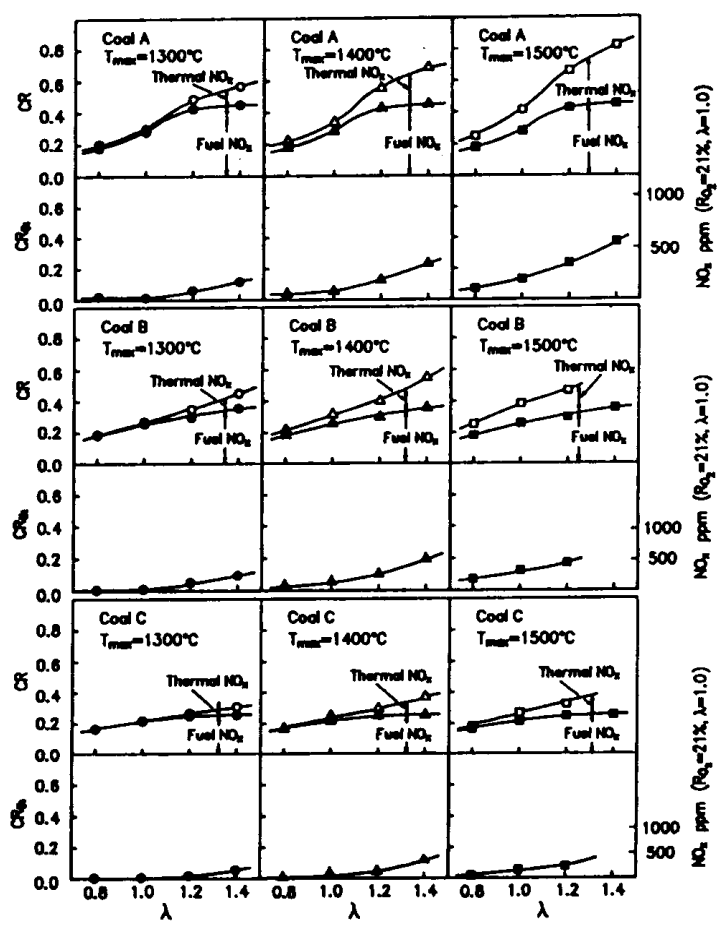

図 $6 \mathrm{NO}$ 生成に及ほす酸素過剩率の影䇾 
いずれの条件下でも，図 5 と同様な抾大 Zeldovich 機

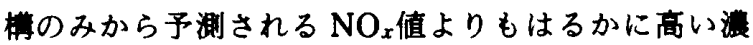
度のサーマル $\mathrm{NO}_{x}$ が襀測されている。

\section{4 原炭中 $\mathrm{N}$ 分含有率の影零 $\mathrm{A}$ 炭 $(N=0.79$} \%) と B 炭 $(N=1.50 \%)$ の場合の結果の比較から, $N$ 以外はほほ等しい条件下での $\mathrm{N}$ 分含有率の影零につ いて整理したものが図 7である。サーマル NOxについ ては，基準值換算濼度で示してある。フュエル $\mathrm{NO}_{x}$ に ついては, $\mathrm{N}$ 分が多い炭種ほど変換率 $C R_{f}$ が隇少す る傾向が，特に入>1で明りょうに現れている。この結

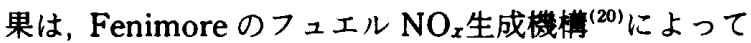

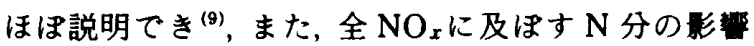
を検討した結果 ${ }^{(21)} と も$ 良く対応している。一方，サー

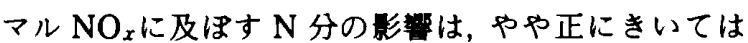
いるが全体としては小さいものであり，例えば， $\lambda=$ $1.2, \quad T_{\max }=1500^{\circ} \mathrm{C}$ の場合, $N$ がほほ 2 倍になって もサーマル $\mathrm{NO}_{x}$ の増加割合は $20 \%$ 以内である。

3.5 原炭中挥発分含有率の影 $\mathrm{B}$ 炭 $(V M=$ $40.8 \%)$ と C 炭 $(V M=26.1 \%)$ による結果の比較から, $V M$ のみの影響を抽出したものが図 8 であり，3・4 節 と同様，サーマル $\mathrm{NO}_{x}$ は基準值換算湌度で示してあ 3. 図 8 から, フェエル $\mathrm{NO}_{x}$ サーマル $\mathrm{NO}_{x}$ も $V M$ の増加とともに增大することがわかる，入>1におい て、VMの増加によりフェエル $\mathrm{NO}_{x}$ が增大するのは, $V M$ が大きいほど原炭中 $\mathrm{N}$ 分の揮発分中への分配割 合が大きく，また，チャー中残留 $\mathrm{N}$ 分の $\mathrm{NO}_{x}$ への変 換率は小さいことから，揮発分中 $\mathrm{N}$ 分起源のいわゆ る Volatile $\mathrm{NO}_{x}$ が増加するためであると考えられ る.ただし，入が小さくなると，VMが大きいほうが揮 発分燃烧による $\mathrm{O}_{2}$ 消费が速いため，揮発分中 $\mathrm{N}$ 分の $\mathrm{HCN} や \mathrm{NH}_{3}$ への変換が增加し $\mathrm{NO}_{x}$ への変換が減少 する ${ }^{(8)}$.このため, $C R_{f}$ に及ほす $V M$ の影䈉は小さく なり, $\lambda<0.7$ 程度になると $V M$ の効果は逆転するこ と界が予想される。

一方, サーマル $\mathrm{NO}_{x}$ の生成量は $V M$ とともに增加 し，この傾向は $T_{\max }$ が高いほど影著であることがわ かる。例えば, $\lambda=1.2, \quad T_{\max }=1500^{\circ} \mathrm{C}$ の場合, $V M$ の $56 \%$ 增加に対してサーマル $\mathrm{NO}_{x}$ 湌度は $40 \%$ 程度 も增加している。この結果は，揮発分燃焼域では粒子 まわりに粒子から離れた火炎帯が形成され，燃料過湠 のこの火炎带内側では，撣発分として放出された炭化 水素が空気中の $\mathrm{N}_{2}$ と反応して $\mathrm{HCN}$ や $\mathrm{NH}_{i}$ が生成さ れここれら中間体が酸素あるいは酸素原子を含むラ ジカル（主として $\mathrm{OH}$ ) と反応して $\mathrm{NO}_{x}$ ，すなわちプロ ンプト $\mathrm{NO}_{x}$ を生成すると考えることにより説明でき る。すなわち, $V M$ が大きい,あるいは $T_{\max }$ が高いほ
ぞ，粒子まわりの炎帯の最大広がりが大きくなるた め上記の中間体の生成が促進され，プロンプト $\mathrm{NO}_{x}$ の生成量が多くなると考えることができる。

\section{4. サーマル NO 生成に间する理龢解析}

微粉炭燃焼におけるサーマル $\mathrm{NO}_{x}$ に関する実験的 検討の結果，条件によっては, Zeldovich 機構から予 測される值よりはるかに多量のサーマル $\mathrm{NO}_{x}$ が生成 されること，また，粒子まわりの火炎帯におけるプロ ンプト $\mathrm{NO}_{x}$ の生成を考えると実匼結果の傾向を良く 説明できることを明らかにした。ここでは，揮発分然


庴流拡散火炎の反応動力学計算 ${ }^{(22)}$ を組合せることに より，粒子まわりにおけるサーマル $\mathrm{NO}_{x}$ の生成挙動 に関する理論解析を行い，実際，粒子まわりでどのく らいプロンプト $\mathrm{NO}_{x}$ が生成され得るのか, 拉大 Zeldovich 機構だけで生成するサーマル $\mathrm{NO}_{x}$ はどのくら いか，また，これらが平均サーマル $\mathrm{NO}_{x}$ 湌度にどのく らい寄与するのか, という点を中心に検討を行った。 したがって，本解析では，反応素過程の詳細な議論や， サーマル $\mathrm{NO}_{x}$ 漂度を正確に予測するモデルの確立を 目的としているわけではないのて，解析にあたっては， 本質をそこなわない範囲で，でるだけ簡単化された モデルを採用することにする。

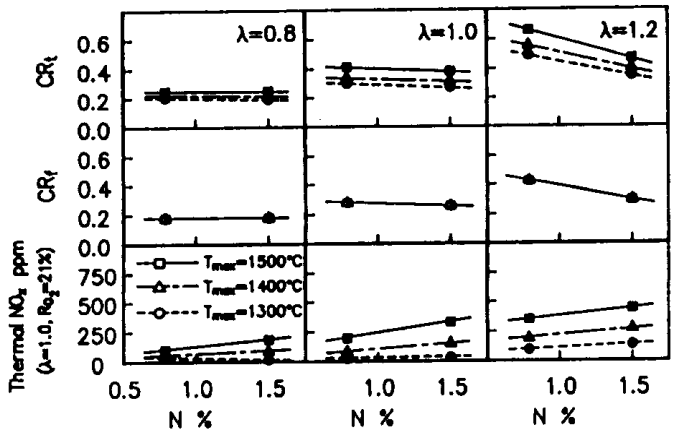

図 $7 \mathrm{NO}_{x}$ 生成に及ほす原茏中空素分の影䈏

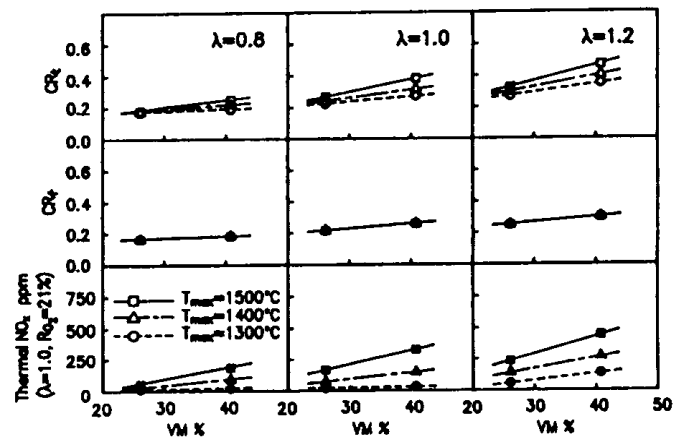

図 8 NOx生成に及ほす原若中撣発分の影管 
$4 \cdot 1$ 解析モデル 解析で用いられた主な仮定は 次のとおりである。

（1）粒子は均質な球形でガスとのスリップもな く，現象は非定常一次元球対称である.

（2）すべての物性値は一定とする.

（3）揮発分は単一成分の $\mathrm{CH}_{4}$ のみとする。

（4）固相の燃焼は粒子表面のみで起こり， $\mathrm{O}_{2}$ およ び $\mathrm{CO}_{2}$ により酸化される.

（5）粒子径は燃焼中一定である.

（6）半径方向速度分布は，揮発分および燃焼生成 物の噴出速度より決め，運動量保存式は解かない。

（7）ガス温度および粒子温度は一定值で与え，工 ネルギー保存式は解かない.

以上の仮定のもとで, 基礎方程式としては，球座標 における気相中での連続の式と化学種保存式, および, 固相の質量保存式となる。

境界条件としては，次のように与えた，外側境界で は，均一分散微粉炭粒子一個当たりの占有空間体糟に 相当する球の半径（ $\lambda=1.2$ では粒子半径の約 40 倍）に おいて, 対称条件から, 各化学種の漂度こう配を零と おいた。内側境界すなわち粒子表面では，揮発分の放 出流束および表面反応速度を考虑して, 半径方向速度 を与えた。初期条件としては，微粉炭粒子と周囲空気 が，時刻 $t=0$ において突然，設定温度 $T$ (一定)にな ったと考え，また，化学種の渻度としては， $\mathrm{O}_{2}, \mathrm{~N}_{2}$, $\mathrm{CO}_{2}$ につては空気中の㴤度, 他の化学種については 零で与えた。

$4 \cdot 2$ 反応モデル 熱分解による微粉炭粒子から

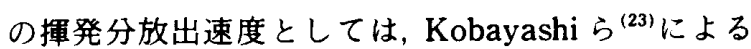
2 ステップ反応モデルを 1 ステップ反応で近似して用 い，また，粒子表面での固定炭素の酸化反応速度とし

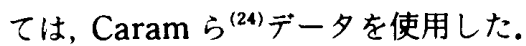

気相反応モデルとしては，NOxはすべて $\mathrm{NO} と し ，$ また,フュエル $\mathrm{NO}_{x}$ の生成過程は考虑せずサーマル NOx のみについて考えた。 $\mathrm{N}$ を含む化学種の関与する 反応としては，次の 12 個 ${ }^{(22)}$ を考虑に入れた。



$$
\begin{aligned}
& \mathrm{N}+\mathrm{O}_{2}=\mathrm{NO}+\mathrm{O} \\
& \mathrm{O}+\mathrm{N}_{2}=\mathrm{NO}+\mathrm{N}
\end{aligned}
$$

揮発分として放出された $\mathrm{CH}$.のフラグメントが空 気中の $\mathrm{N}_{2}$ と反応し〔反応(1))，この反応によって生 じた HCN，NHがCN，Nとなり〔反応(2)，(5))，

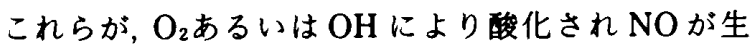
成する. 反応 $(10) \sim(12)$ が拡大 Zeldovich 機構による 反応に相当する，計算は，文献(22)を参照して，20 個 の化学種，および 44 の素反応を考虑して行ったが, 11 の素反応の速度定数については新しいデータ ${ }^{(25)} に$ 変 更している，生成項の線形化 ${ }^{(16)}$ な゙を行ったうえで, 時間微分については前進差分, 空間微分については中 心差分を用いて基整式を差分化し，数値計算を行っ た。また, プロンプト $\mathrm{NO}_{x}$ と Zeldovich $\mathrm{NO}_{x}$ の比較の ため, 反応(1)を停止し, Zeldovich $\mathrm{NO}_{x}$ の生成量を あわせて計算した。

4.3 計算結果と考察計算結果の一例として， $1700 \mathrm{~K}$ の一様温度場に粒径 $70 \mu \mathrm{m}$ の A 炭の微粉炭 粒子を置いたときの, 粒子まわりにおける主要化学種 分布の経時変化を図 9 に, $\mathrm{N}$ 含有化学種分布の経時変 化を図 10 に示す.図 9 中の $\mathrm{HC}$ は, $\mathrm{CH}_{4}, \mathrm{CH}_{3}, \mathrm{CH}_{2}$ の 濃度の和である.図 9 での $\mathrm{O}_{2}$ と $\mathrm{HC}$ の交点を火炎帯中 心と考えると， $t=1 \mathrm{~ms}$ では，すでに火炎带は粒子半 径の約 9 倍の $310 \mu \mathrm{m}$ にまで広がっている. 本モデル では予熱時間を考えていないので，この状況に至るま での時間は，実際の燃焼場よりはるかに短くなってい る。このとき， $\mathrm{N}_{2}$ は粒子表面にまで存在しており，火 炎帯内側の燃料過瀿領域で, 図 10 に示すように, プロ ンプト $\mathrm{NO}_{x}$ 生成のもとになる $\mathrm{HCN}, \mathrm{NH}$ が多量に生 成されている。これらが $\mathrm{CN}, \mathrm{N}$ を経由して，火炎帯中 心のやや外側で多量のNOの発生につながっている。 時間の経過とともに火炎帯は再び粒子表面に戻ってい くが, 火炎帯外部での NO 湿度は拡散のため上昇して いる.

粒子まわりの Zeldovich 機構による $\mathrm{NO}_{x}$ とサーマ ル $\mathrm{NO}_{x}$ の滇度分布を, $t=5 \mathrm{~ms}$ の場合において比较し たものが図 11 である.サーマル $\mathrm{NO}_{x}$ 湛度の最大值は 約 $30 \mathrm{ppm}$ であり, Zeldovich $\mathrm{NO}_{x}$ の約 $0.4 \mathrm{ppm}$ より はるかに大きく，微粉炭燃焼場でのサーマル $\mathrm{NO}_{x}$ の

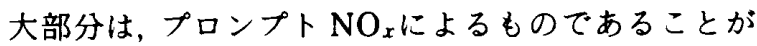
明らかにされた。このようにして生成されたサーマル $\mathrm{NO}_{x}$ がガス中平均濃度としてどのくらいになるのか を，経過時間に対して示したのが図 12 である，粒子の 温度上昇(14)を考虑すれば，実測された多量のサーマル $\mathrm{NO}_{x}(3 \cdot 1$ 節) のかなりの割合が, 粒子まわりの火炎帯 内でのプロンプト $\mathrm{NO}_{x}$ の生成により説明がつくこと 




(a) $t=1 \mathrm{~ms}$

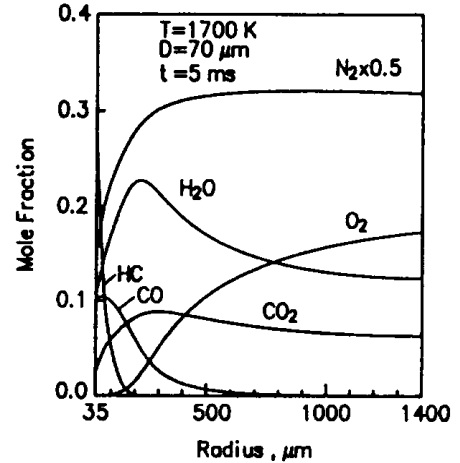

(b) $t=5 \mathrm{~ms}$

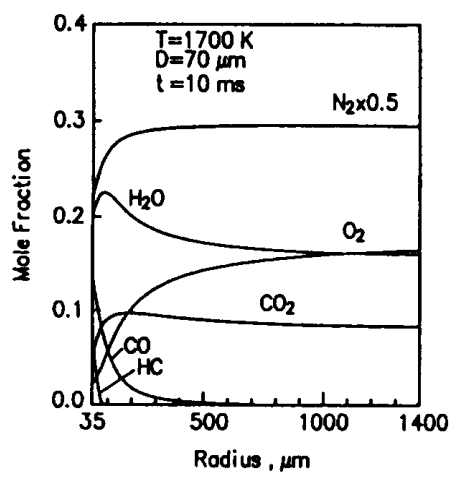

(c) $t=10 \mathrm{~ms}$

図 9 微粉炭粒子まわりの火炎帯内における主要安定化学 種眼度分布の経時変化

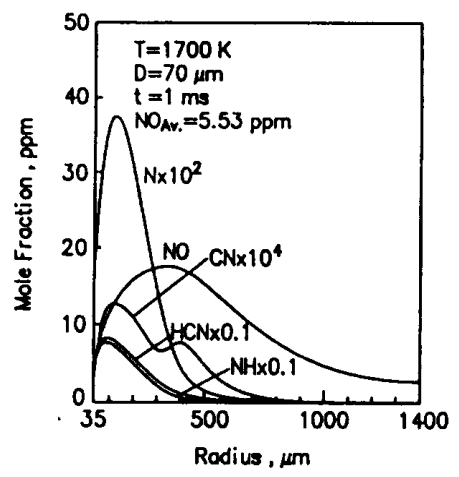

(a) $t=1 \mathrm{~ms}$

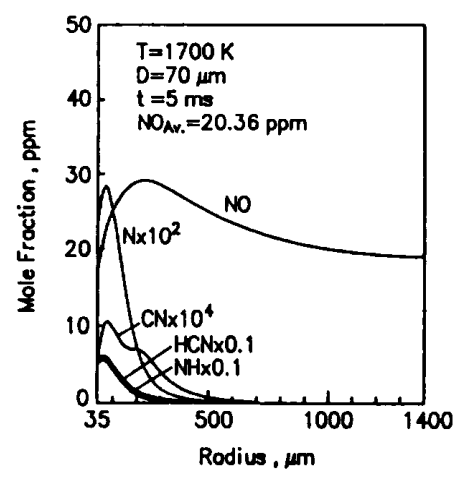

(b) $t=5 \mathrm{~ms}$

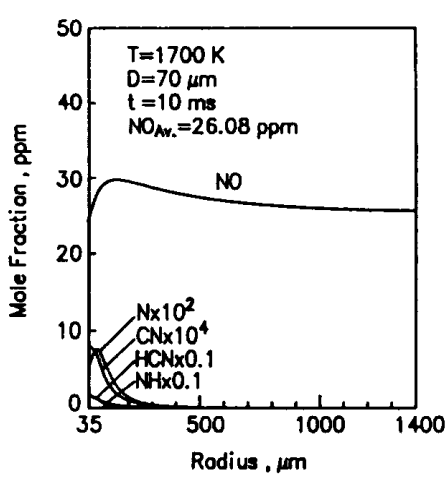

(c) $t=10 \mathrm{~ms}$

図 10 微粉炭粒子まわりの火炎帯内における窒素含有化 学種漕度分布の経時変化

がわかる，実際の微粉炭燃焼では，粒子き裂からの揮 発分の噴出による粒子の複雑な飛行運動や回転運 動 ${ }^{(26)}$ が存在し，本モデルほど単純ではないが，サーマ ル $\mathrm{NO}_{x}$ に対するプロンプト $\mathrm{NO}_{x}$ の寄与がきわめて大 きなものであることは確かである。

図 13 は, $\mathrm{NO}_{x}$ の平均箵度の経時変化に及ほす初期 酸素㵋度 $R_{\mathrm{O}_{2}}$ の影響を示しており，3・2 節で述べたと おり， $R_{\mathrm{O}_{2}}$ のサーマル $\mathrm{NO}_{x}$ 生成に及ほす影響はきわめ て小さい.図 9,10 と同様な計算の結果, $R_{\mathrm{O}_{2}}=27 \%$ の場合, $t=1 \mathrm{~ms}$ での火炎帯中心の半径は約 $260 \mu \mathrm{m}$ であり， $R_{0_{2}}=21 \%$ の場合より粒子まわりの火炎帯が かなり縮小する。このため $\mathrm{HCN} ゃ \mathrm{NH}$ の生成領域も 縮小してプロンプト $\mathrm{NO}_{x}$ の生成が減少し, サーマル $\mathrm{NO}_{x}$ に及ほす $R_{\mathrm{O}_{2}}$ そのものの正の奇与が全体として 相殺されたものと解釈することができる。

\section{5. 转}

微粉炭燃焼におけるフュエル $\mathrm{NO}_{x}$ とサーマル $\mathrm{NO}_{x}$ の生成挙動を分睢し，それぞれに及ほす燃焼条件や炭 種性状などの諸因子の影警を系統的に明らかにすると

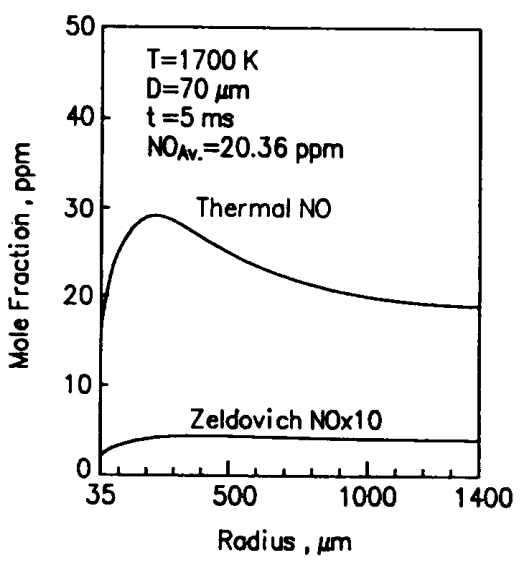

図11粒子まわりにおけるサーマル $\mathrm{NO}_{x}$ と Zeldovich $\mathrm{NO}_{x}$ の灌度分布の比較

ともに，そのメカニズムについて理論解析を合せて検 討を行った。その結果得られた主な結論は次のとおり である。

（1）微粉炭燃焼におけるサーマル $\mathrm{NO}_{x}$ の生成量 は，火炎温度に対するZeldovich 機粠から予測される 值よりもはるかに大きく，この差は，揮発分燃焼域で 


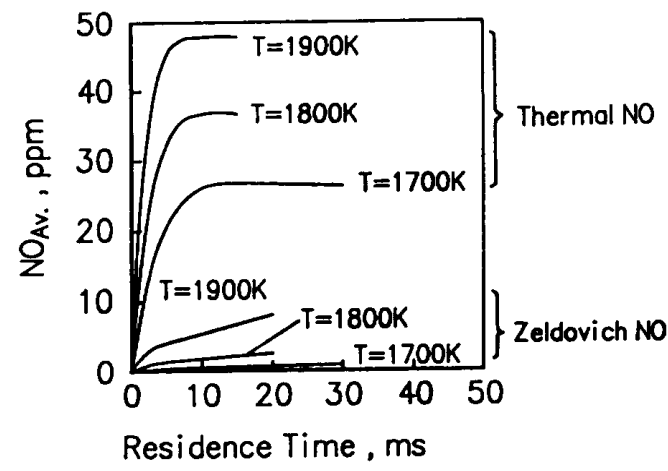

図 12 サーマル $\mathrm{NO}_{x}$ と Zeldovich $\mathrm{NO}_{x}$ の平均湍度の 経時変化に対する温度の影信

の粒子温度の上昇に加え, 粒子まわりの火炎带内で生 成するプロンプト $\mathrm{NO}_{x}$ の寄与によるところが大きい。

（2）フェエル NOx生成量の火炎温度依存性はき わめて小さいが,サーマル $\mathrm{NO}_{x}$ の生成は, 温度上昇と ともに増大する，この㑯向は, 酸素過剩率が高いほど, 原炭中揮発分含有率が高いほど顝著である。

（3）揮発含有率が高いほど, サーマル $\mathrm{NO}_{x}$ の生 成量は大きくなる。これは, 揮発分燃焼域で, 揮発分含 有率が高いほど粒子温度上昇が大きく，さらに，粒子 まわりの火炎帯の拡大によるプロンプト $\mathrm{NO}_{x}$ の生成 量が增加するためである。

(4) 等しい火炎温度のもとでは, サーマル $\mathrm{NO}_{x}$ の生成量は初期酸素湛度にほとんど依存しない。これ は，初期酸素灣度が高いと，粒子温度は高くなるが， 逆に粒子まわりの火炎帯が樎小して, プロンプト $\mathrm{NO}_{x}$ の生成が抑えられるためである。

\section{文献}

(1) Pershing. D. W. and Wendt. J. O. L., Proc. 16th Symp. (Int.) Combust., (1977), 389.

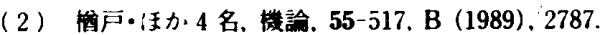

(3) Ohtake. K. (Feng, J., ed.). Coal Combustion. (1988), 65. Hemisphere.

(4) Pershing, D. W. and Wendt. J. O. L., I \& E. C. Process Des. Detelop., 18-1 (1979), 60.

(5) Pohl, J. H. and Sarofim. A. F.. Proc. 16th Simp. (Int.) Combrst.. (1977), 491.

(6) Wendt. J. O. L.. 活か3名. Proc. 17th Simp. (Int.) Combrst.. (1979), 77 .

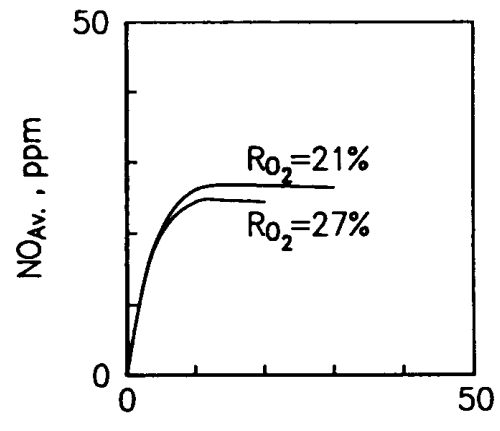

Residence Time, ms

図 13 サーマル $\mathrm{NO}_{x}$ の平均湍度の経時変化に対する 初期酸素湍度の影暗

(7) Altenkirch. R. A., ほか 2 名. Combust. Sci. Techmol.. 20 (1979), 49.

(8) Chen. S. L., 隹か3名. Proc. 19th S.mp. (Int.) Combist.. (1982), 1271.

（9）岡崎・活か３名，機論、51-465, B (1985)，1549.

(10) Hill. S. C.. ほか 2 名, Proc. 20th Simp. (Int.) Combust.. (1984), 1391.

(11) Fenimore. C. P.. Proc. 13th Symp. (Int.) Combust., (1971). 373.

（12）高城・活か３名，譏論、44-388（1978），4282.

（13）森編，燃焼に伴う環境污染物質の生成機構上抑制法。 (1980)，45，日本機械学会。

(14) Takeshi. M. and Okazaki. K. (Feng. J.. ed.). Coal Combustion. (1988), 139. Hemisphere.

（15）森・活， 2 名，機論，42-357 (1976)、1511.

（16）宮内・活か2 名, 機論, 45-400 (1979), 1913.

(17) Bachmaier, F.. 伍名, Combust. Sci. Teclunol.. 7 (1973), 77 .

（18）加藤・活力３名，機論，42-354（1976），582.

（19）加藤・活加 3 名，機論。 42-354 (1976)，592.

(20) Fenimore, C. P.. Combust. Flame. 19 (1972), 289.

(21) Okazaki, K.. 湫力 3 名(Feng. J., ed). Coal Combustion. (1988). 821. Hemisphere.

（22）森・伍加 3 名。機諭，46-410. B (1980)，2052.

(23) Kobayashi. H., 活か2 2 名. Proc. 16th Simp. (Int.) Combrist. (1977), 411.

(24) Caram. H. S. and Amundson, N. R., Ind. Eng. Chem. Fundam.. 16 (1977), 171.

(25) Charles. K.. 湫名. Chemical Kinetics and Thermochemical Data for Combustion Applications. (1982). Lawrence Livermore Lab., Lniv. of Calif.

(26) Beer. J. M. (Feng. J., ed.), Coal Combustion, (1988). 1. Hemisphere. 